\title{
Research on Enhancing and Strengthening Sense of Professional Duty of Teachers of Ideological and Political Courses with "Four Matters of Confidence"
}

\author{
Liu Xiaoyuan ${ }^{1 *}$, Liu Juntao ${ }^{1}$ \\ School of Marxism, Huali College Guangdong University of Technology, Guangzhou, Guangdong Province, 511325, \\ China. \\ *Corresponding author. Email: $158389631 @ q q . c o m$
}

\begin{abstract}
In the new period of educational development, teachers of ideological and political courses in colleges and universities should always uphold the socialism with Chinese characteristics and have firm confidence in its path, system, theory and culture, be deeply aware of the value of social development of ideological and political courses, comprehensively improve the theoretical attainment and professional skills of Marxism, comprehensively strengthen the sense of mission and responsibility for personal development, improve the quality and effectiveness of teaching, develop ideological and political courses into courses that benefit students for a lifetime, and provide effective guidance for the all-round development of students in the future.
\end{abstract}

Keywords: Four matters of confidence, Teachers of ideological and political courses, Sense of professional duty, Path

\section{INTRODUCTION}

In recent years, with the gradual implementation of Opinions on Political Education of College Students, more higher requirements have been put forward for the personal career development of teachers of ideological and political course in colleges and universities, which has promoted the gradual enhancement of teachers' sense of mission and the effectiveness of students' learning and education. From the current development situation of some teachers of ideological and political courses, some teachers have poor performance in personal sense of mission and sense of responsibility, are lack of professional ideals and have no enough self-confidence in the teaching process, which will lead to a big gap between the teaching effectiveness of ideological and political courses and the people's expectations for development. Since the 18th CPC National Congress and the 19th CPC National Congress, when comprehensively strengthening the sense of mission of teachers of ideological and political courses in colleges and universities, we should always adhere to the basic value guidance of confidence in path, theory, system and culture. Thus we can not only improve the sense of responsibility and sense of mission of teachers of ideological and political courses, but also comprehensively strengthen the teaching effectiveness, which plays an important role in effectively promoting the growth and development of college students.

\section{COMPREHENSIVELY RECOGNIZING THE SOCIAL VALUE OF DEVELOPMENT OF IDEOLOGICAL AND POLITICAL COURSES BASED ON THE SOCIALIST MODERNIZATION CONSTRUCTION}

College students are important resources of human talents in the development of socialist modernization. They shoulder the heavy responsibility of historical development of realizing the great Chinese dream and the great rejuvenation of the Chinese nation and are the future of the development of the country and the nation. The personal values, value orientation and ideological and moral qualities of college students have great influence on the construction and development of the great socialist cause. When receiving higher education, students are also establishing their ideological and moral qualities and personal values. At this stage, they should realize the importance of the cultivation of ideological and moral qualities and personal values. From the current situation of ideological development of many college students in our country, we can see that many 
students generally have healthy and positive mind, show love of the country, the Party, the general public and socialism in their daily learning and life, and firmly support and safeguard the Party's development policy and many theoretical policies. Advanced students have a good spirit of exploration, can take the initiative to learn all kinds of new things, and are fully confident in realizing the great rejuvenation of the Chinese nation. However, with the acceleration of the process of economic globalization and the increasingly complicated international political environment, many erroneous ideas and negative values from western countries have a huge impact on students' ideological values. Some students will be guided by erroneous ideological trend due to their lack of firm beliefs and critical thinking ability. As a result, some students are deficient in correct political beliefs, development concepts, sense of social responsibility, personal development ability, social skills, team-work spirit, etc. There are also some students who are influenced by money worship, extreme individualism and hedonism in the material life, resulting in a lack of positive and hard-working spirit.[1] Therefore, teachers of ideological and political courses in colleges and universities now should actively undertake social and educational responsibilities based on such realities, and guide students to distinguish right from wrong among numerous and complicated theories based on diversified teaching paths of ideological and political courses. Consequently, they can positively lead the right, scientific and standardized direction of development. Learning Marxism can effectively strengthen students' confidence in path, system, theory and culture of the socialism with Chinese characteristics. They can actively advocate the core values of contemporary socialism, promote students' ideological quality to be improved in an all-round way, actively shoulder the heavy responsibility of historical development, and serve as a main force in the construction of socialist cause. This educational function of ideological and political courses cannot be replaced by any other courses and disciplines.[2]

At present, teachers of ideological and political courses in colleges and universities should be aware of the important role of ideological and political courses, which may affect the healthy growth of contemporary teenagers and young people, the success of the development of the socialist cause, and the future and destiny of the nation. By comprehensively raising the awareness of the importance of ideological and political courses, they can effectively strengthen the position consciousness and focus on their social responsibilities and sacred missions. Establishing a major dose of occupation assuredness can effectively strengthen the sense of mission and responsibility, realize effective role setting and separation of duties, and ensure the full play of the social role of ideological and political courses in the new era.

\section{ALWAYS FIRMLY ADHERING TO THE “ FOUR MATTERS OF CONFIDENCE " AND ALWAYS ESTABLISHING CONVICTION ON MARXIST PHILOSOPHY}

Teachers of ideological and political courses in colleges and universities shoulder the mission of cultivating many socialist successors with firm political beliefs. Always firmly sticking to "Four Matters of Confidence", they can consciously establish Marxist ideals and beliefs. In the daily teaching and education work, they should firmly stick to "Four Matters of Confidence" and establish Marxist ideals and beliefs in an all-round way, which is an important foundation for teachers of ideological and political courses to cherish their posts and devote wholeheartedly to work. At present, in order to guide students to strengthen Marxist ideals and beliefs in daily teaching, teachers should be level-headed in political issues and truly understand and stick to Marxist beliefs. In terms of the theory of socialism with Chinese characteristics, they should maintain the greatest trust, in-depth learning, highly efficient teaching and comprehensive practice. They should always consciously and firmly adhere to the "Four Matters of Confidence" and strengthen the path, theoretical system and scientific connotation and cognition of socialism with Chinese characteristics through acute political acumen. They can establish a lofty communist ideal, and take it as an important mission to actively promote the theory of socialism with Chinese characteristics, Marxist theory and proper values in daily teaching. Only in this way can teachers of ideological and political courses stand high and see far. They should clarify the right direction of development and scientific attitude, and can effectively maintain the confidence in teaching. Through the firm belief in Marxist theory, they should lead the students collectively, move students with motion in teaching, guide the students' ideological and moral construction with the right and scientific theories, correct some students' wrong development concepts or ideological understanding, and actively shape a good image for the development of ideological and political courses in the minds of students, which can comprehensively enhance students' trust of Marxism and improve the ideological quality of the students.[3] 


\section{STRENGTHENING PROFESSIONAL IDENTITY AND PROFESSIONAL IDEAL OF TEACHERS OF IDEOLOGICAL AND POLITICAL COURSES THOROUGHLY BASED ON " FOUR MATTERS OF CONFIDENCE"}

Professional identity and professional ideal are the important moral support for teachers of ideological and political courses to be involved in the long-term education, and are the basic premise for actively practicing the development requirements of cherishing posts and devoting wholeheartedly to work. When carrying out activities of ideological and political education in modern colleges and universities, teachers of ideological and political courses play an important role in the implementation of educational activities, and are also important communicators of Marxist theory and the theoretical system of socialism with Chinese characteristics. The degree of personal identification and understanding of the Marxist theory by teachers of ideological and political courses has a great influence on the formation of personal occupation assuredness and professional ideal. It will also affect teachers of ideological and political courses in the pursuit of Marxist theoretical education as a long-term noble profession, which helps to stimulate personal potential at work, to promote them to fully devote themselves to daily work, and to form a higher sense of responsibility, mission and pride in the process of work practice. When students feel it difficult to raise their interest in the professional field they are engaged in, it will play an effective role in promoting students' personal initiative and enthusiasm.[4].

In the answers to questions related to the discipline belongingness of ideological and political courses and the professional support of teachers in colleges and universities, they should focus on highlighting the status of Marxist theory as the first-level discipline, which can ensure the centralized consolidation and establishment of the professional ideals and occupation assuredness of teachers of ideological and political courses. However, at present, teachers of ideological and political courses lack professional identity and fine professional ideals in their own development, which will affect the assessment of professional social values of teachers. Lack of confidence on positive development in teaching activities, and negative emotions with varying degrees for some teachers will lead to the gradual weakening of the personal sense of mission for teachers of ideological and political courses in colleges and universities in the long run. Therefore, they currently should attach importance to comprehensively strengthening the professional ideal and professional identity of teachers of ideological and political courses, which can help them to establish occupation assuredness, fully realize their own professional values, and pay more attention to the development of sense of mission. At present, the collective control of this issue requires teachers of ideological and political courses to effectively stick to "Four Matters of Confidence", fully realize the corresponding social value of Marxist theory, and be able to study Marxist theory as specific social sciences. They should establish the ideal of professional development in education and occupation assuredness in an all-round way, forge ahead with determination, cherish their posts and devote wholeheartedly to work, focus on strengthening teaching results through their own all-round efforts, and realize the social value of ideological and political courses. In the process of development, they can gradually feel the happiness of professional development and the sense of achievement. Through the continuous efforts of teachers of ideological and political courses, the general public can effectively realize the sacred status of this occupation, gradually change the misconception and lopsided misunderstanding for this occupation in the past, and promote the development of ideological and political education in colleges and universities on the basis of highlighting the value and status of teachers of ideological and political courses.[5]

\section{HIGHLIGHTING THE GUIDING POSITION OF "FOUR MATTERS OF CONFIDENCE" AND COMPREHENSIVELY STRENGTHENING THE PROFESSIONAL QUALITY AND PROFESSIONAL COMPETENCE OF TEACHERS OF IDEOLOGICAL AND POLITICAL COURSES}

In terms of the realities, characteristics and division of main teaching tasks of ideological and political education in colleges and universities, teachers of ideological and political courses in colleges and universities should not only cherish an affection for Marxist theory, but also maintain high work enthusiasm and sense of responsibility in the long-term education and teaching practice. Excellent teachers of ideological and political courses should highlight the guiding position of "Four Matters of Confidence", improve personal professional development attainment and development capability, collectively control the law of development of ideological and political course teaching, conduct in-depth study of teaching arts, respond to the needs of students' ideological and political development, fully stimulate students' interest in learning, strengthen the appeal and attractiveness of curriculum teaching, and promote the effective implementation of teaching results of ideological and political courses. As a result, they can feel greater sense of achievement, happiness and professional pride in teaching activities, which can effectively consolidate the sense of mission and honor for career development.[6] 


\subsection{Strengthening learning and personal professional qualities}

At present, in the development of modern ideological and political education, attention should be paid to the active construction of teams for ideological and political teaching with high Marxist theoretical attainment and solid foundation in human sciences. Teachers of ideological and political courses should have rich theoretical knowledge and be conversant with both Eastern and Western learning, which helps to lay an effective foundation for the improvement of teaching results of ideological and political courses. In the development of teachers of ideological and political courses themselves, their theoretical level has a great influence on the teaching results. Therefore, teachers of ideological and political courses should strengthen their personal theoretical attainment, improve their theoretical learning ability, maintain a positive attitude towards Marxist theoretical research in daily teaching and research activities, and collectively control the quintessence and spiritual essence of Marxism and the complete theoretical system of socialism with Chinese characteristics. They should also consider the realities of social development, effectively relate the theory to the realities of social development, fully highlight the insight and acumen of Marxist theory, focus on many new problems in the development of social practice, and intensively explain various complex problems in social development and socialized problems receiving much attention through Marxism, which can guide students to correctly analyze and handle them. The teaching of ideological and political courses is highly comprehensive, mainly involving pedagogy, economics, philosophy, psychology, literature, ethics, history and many other disciplines. In daily teaching, they should integrate multi-disciplinary knowledge to provide support, and are required to not only increase their personal professional theoretical knowledge, but also realize the accumulation of multi-disciplinary knowledge. In the teaching, concentrated demonstration with multi-party cases can effectively strengthen the teaching appeal and persuasiveness, optimize the teaching success, enhance the teaching charm of teachers [7].

\subsection{Optimizing the art of teaching and improving professional teaching ability}

In the new period, excellent teachers of ideological and political courses in colleges and universities should have strong teaching ability which is a basic skill and an important foundation for strengthening teaching results and promoting students' efficient learning. At the present stage, teachers of ideological and political courses should intensively convey the teaching contents they have mastered to students. They should not only have good theoretical attainment, but also actively integrate scientific educational theories. They can collectively integrate different teaching methods and measures, improve teaching results, and fully realize high-standard teaching development goals through scientific theoretical practice. This requirement shows that teachers of ideological and political courses should establish more advanced teaching concepts, highlighting the dominant position of students and secondary guiding position of teachers. In the teaching process, they should strengthen the connection between students' everyday learning and realities and follow the development concept of teaching students in accordance with their aptitude. The situation should be changed that traditionally teachers occupy the leading position in teaching and teaching concepts are taught unilaterally. Teaching methods and measures should be formulated to meet students' cognitive competence and learning requirements, so as to help students to accept relevant teaching contents precisely. Teachers of ideological and political courses should timely and effectively transform the existing teaching material system into a teaching system and carry out the centralized transformation of the theoretical system of socialism with Chinese characteristics. As an important practical path for students to analyze and answer problems, it can actively stimulate students' enthusiasm for learning and promote ideological and political teaching content to truly be borne in mind by students. Only in this way can students be guided to effectively turn various theories and thoughts into practical behaviors, so as to improve their personal ideological quality and realize their all-round development.

\subsection{Improving professional ethics and highlighting personality charm}

Teachers of ideological and political courses in colleges and universities are mainly responsible for guiding the spread of Marxism and the healthy growth of students in their personal development. They are important communicators of Marxist theoretical knowledge and important demonstrators of noble morality, advanced ideas and perfect personality. Therefore, in order to improve the teaching results of ideological and political courses in an all-round way, it is not enough merely relying on Marxist theory. At present, it is necessary to focus on highlighting teachers' personality charm. The personal moral sentiment and personality charm of teachers of ideological and political courses belong to implicit educational power and teaching measures. They are also the source of strength to inspire and guide students to develop in an all-round way, posing a wide-ranging, in-depth and lasting impact on promoting the development of moral quality and the establishment of ideal personality of students. Virtuous teachers can have a positive effect on students' inner environment through their personality charm, and ensure that they can establish positive 
emotional resonance with students in daily teaching, which can help to stimulate students' learning enthusiasm, strengthen students' recognition of curriculum teaching, and realize the educational goals of conscious learning and active learning. Teachers of ideological and political courses are required to comprehensively strengthen their moral cultivation, and guide students to develop in an all-round way through their excellent moral character, noble sentiment and broad mind. In this process, they can deeply realize the importance of their profession and strengthen their sense of mission and honor for personal development.[8]

\section{CONCLUSION}

At the present stage, it is a systematic development project to comprehensively strengthen the sense of mission of teachers of ideological and political courses, and it is difficult to effectively realize it by relying unilaterally on the subjective efforts of teachers themselves. At this stage, different parties including government agencies as well as colleges and universities should thoroughly implement various policies and instructions of ideological and political courses and actively construct a social support system. The working and development environment for teachers of ideological and political courses should be optimized in an all-round way, serving as a good external development environment for their future study and life, and providing effective support for strengthening the sense of mission of teachers of ideological and political courses.

\section{SUBJECT}

This paper is a preliminary research result of Educational Science Planning Project of Guangdong "Research on Improving the 'Occupation Assuredness' of Teachers of Ideological and Political Courses in Colleges and Universities-Based on Career Development Theory" (Project No. 2018GXJK252)

\section{REFERENCES}

[1] Li Li, Cai Pumin. Promoting and Strengthening the Sense of Professional Duty of Teachers of Ideological and Political Courses with "Three Matters of Confidence". Leading Journal of Ideological \& Theoretical Education. 2014(9): 95-97.

[2] Zhang Haoyi. On the Construction of Teachers in Higher Vocational Colleges under the Background of "Ideological and Political Theories teaching in All Courses". Tea in Fujian, 2020, 42(4): 249.

[3] Sun Jie, Hua Ye, Wang Zhen. Rational Reflection on Vocational Teachers' Professional Quality from the Perspective of "Ideological and Political Theories
Teaching in All Courses". Journal of Hubei Open Vocational College. 2020, 33(3): 75-76, 81.

[4] Cui Hongli. On Improving College Ideological and Political Teachers' Professional Happiness in the New Era. Journal of Huainan Vocational \& Technical College. 2020, 20(1): 9-11.

[5] Li Lin. Analysis of Occupation Assuredness and Improvement Paths of Teachers of Ideological and Political Courses in Colleges and Universities in the New Era. Theoretic Observation. 2020(4): 147-150.

[6] Wang Qian. The Causes and Solutions of Job Burnout of College Ideological and Political Course Teachers. The Science Education Article Collects. 2019(34): 150-151.

[7] Sun Jie, Hua Ye, Li Mingmin. A Research on the Effective Integration of "Curriculum Ideology and Politics" Teaching and Higher Vocational College Teachers' Career Development. Journal of Jiangxi Vocational and Technical College of Electricity, 2020, 33(5): 25-27.

[8] Li Peili, Zhang Jinwei. Professional Responsibility: A New Perspective of Research on Development of Teachers of Ideological and Political Courses in Colleges and Universities. Education Exploration. 2019(6): 87-90. 